\title{
Effect of Training, Motivation and Work Environment on Physicians' Performance
}

\author{
Anwar Prabu Mangkunegara
}

Rela Agustine

Mercu Buana University, Jakarta; Email :anwar.mangkunegara@gmail.com

Doi:10.5901/ajis.2016.v5n1p173

Abstract

The study sought to establish and to analyze the effect of training, motivation and work environment on physicians' performance at X Hospital both partially and simultaneously. This statistic parametric study adopted a quantitative method that used a multiple linear regression in which the data were processed by SPSS 21 program. Sample size was 84 targeting physicians as respondents. A structured questionnaire was used by a 1-5 Likert scale. Findings of this study showed that training, motivation and work environment had positive significant effect simultaneously on physicians' performance. Furthermore, training in partially had no significant effect on physicians' performance meanwhile motivation and work environment in partially had significant effect on physicians' performance.

Keywords: Training, Motivation, Work Environment, Physicians' Performance

\section{Introduction}

\subsection{Background of Study}

The ASEAN Economic Community (AEC) is scheduled to come into full operation in 2015. It presents many challenges and opportunities for enterprises across the region. Hence, human resources should be managed optimally and continuity in order to enterprises enables to gain competitiveness by qualified and competent human resources. To develop an optimal employee's performance, it is necessary appropriate strategies through learning process continuously. In addition to having a role as social beings, human resource also serves as a developmental resource which has psychological aspects such as motivation, productivity and professionalism at workplace.

Employee performance is one of important things to improve their productivity, and then it will automatically determine the company performance as well as medical practices at hospital. The hospital performance can be seen from some indicators used to measure the level of utilization, quality and efficiency of services, i.e. these are Bed Occupation Rate (BOR), Average Length of Stay (AVLOS), Turn over Interval (TOI) and Gross Death Rate (GDR). BOR indicates the parameter of utilization level of hospital beds with ideal range $60-85 \%$. However the average BOR on inpatient care at $X$ Hospital respectively declined in 2011-2013. Furthermore, AVLOS indicates an overview the efficiency and quality of hospital services. It has ideally range 6-9 days but X Hospital has not reached the expected minimum AVLOS in 20112013, that was less than 6 days except surgical care units and Class III. Meanwhile, TOI indicates an overview the efficiency of the used bed. Ideally, an unallocated bed is in the range 1-3 days. However, the vacancy was still found at inpatient pavilion care more than 6 days since 2013. Last, GDR indicates general mortality rate of patients. At X hospital was occurred increasing deaths at CVCU and ICU in 2011-2013.

Table 1 is known physicians' performance concerning patients' rehabilitation services in three phases which tend to decline. Phase I is physicians' atempts in managing patients during treatment care; phase II in which the patients are decided whether they are discharged or still need hospitalized after surgical treatment. Meanwhile phase III is defined whether the patients undergo rehabilitation program independently or physical examination. In this phase, there was a significant decrease in the number of patients due to the increasing number of hospital-type class A particularly on foreign private hospital since they are completed with modern diagnostic facilities, experienced physicians and simply medical services bureaucracy. Following is physician performance on rehabilitation care at $\mathrm{X}$ hospital generally decreased in 2011-2013. 
Table 1. Rehabilitation Care Performance (2011-2013)

\begin{tabular}{clccc}
\hline \multirow{2}{*}{ No } & \multirow{2}{*}{ Rehabilitations } & \multicolumn{3}{c}{ Number of Patients } \\
\cline { 3 - 5 } & & 2011 & 2012 & 2013 \\
\hline 1 & Phase I & 4.604 & 6.347 & 4.537 \\
2 & Phase II & 6.347 & 6.387 & 7.896 \\
3 & Phase III & 10.703 & 4.526 & 4.276 \\
\hline
\end{tabular}

Source: Medical Record X hospital 2011-2013

According to the data above, it analyzes that X hospital needs many circumstances to improve medical stakeholders' competencies especially on physicians in serving their patients optimally. One of the ways to improve the performance is through human resource training program.[Daft, L.R,2010] Furthermore, there are no standard rules for education and training for advanced interventional cardiology. So far, cardiologist training is being organized by Cardiovascular College that guides them in improving medical cardiology skills. This results in the need of physician training at $X$ hospital which is still lacking and needs to be improved. Indeed, there is already some cardiovascular training abroad, but the costs involved are relatively expensive while the fund allocation of $X$ hospital tends to prior on medical equipments and physical buildings repairment. Therefore, the efforts for human resource development in improving the skills and knowledge through physician training have not been considered.

Besides, motivation also has an important role in improving employee performance.(Noe, R.A,2012).According to Maslow's theory, motivation is illustrated as a cone; that people will be motivated if their needs such as their living targets are completely accomplished ranging from physiological needs to self-actualization needs[Mullins, J.L,2005]However, the spirit to attain self-achievement or self-actualization needs of physicians at $X$ hospital was still low. Table 2 showed only 13 of 84 physicians at $X$ hospital have educational background as doctorate and 2 physicians who already become professors. While physicians as a consultant only amounted 26 and those who are not titled consultant about 58 . It could be seen that physicians who have not continued to doctoral academic program and consultant was still high. Based on interviews result to several physicians who have not continued doctoral program, they found no sufficient passion for writing scientific papers or continuing their study to higher level since they focus on serving patients though they also realize those needs are extremely important.

Table 2. Physicians at $X$ hospital 2014

\begin{tabular}{|c|c|c|c|c|c|c|c|}
\hline \multirow{2}{*}{ Medical Specialist } & \multirow{2}{*}{ Amount } & \multicolumn{3}{|c|}{ Academic } & \multirow{2}{*}{ - Prof } & \multirow{2}{*}{$C^{*}$} & \multirow{2}{*}{$\mathrm{NC}^{*}$} \\
\hline & & Bachelor & Master & Doctor & & & \\
\hline Cardiovascular Thoracic Surgeons & 10 & - & 8 & 2 & - & 5 & 5 \\
\hline Cardiologist & 43 & & & & & & \\
\hline Pediatrician & 3 & - & 32 & 11 & 2 & 21 & 22 \\
\hline Radiologist & 3 & - & 3 & - & - & - & 3 \\
\hline Neurologist & 1 & - & 3 & - & - & - & 3 \\
\hline Clinical Nutrition & & - & 1 & - & - & - & 1 \\
\hline Specialist & 1 & - & 1 & - & - & - & 1 \\
\hline Pulmonologist & 1 & & & & & & \\
\hline Pathologist & 2 & - & 1 & - & - & - & 1 \\
\hline Anesthesiologist & 12 & - & 2 & - & - & - & 2 \\
\hline Dentist & 3 & - & 12 & - & - & - & 12 \\
\hline & & 2 & 1 & - & - & - & 3 \\
\hline General Practitioner & 5 & 5 & - & - & - & - & 5 \\
\hline TOTAL & 84 & 7 & 64 & 13 & 2 & 26 & 58 \\
\hline
\end{tabular}

${ }^{*} \mathrm{C}$ : Consultant ${ }^{*} \mathrm{NC}$ : Not Consultant

Source: Human Resource Division at X Hospital (2014)

Work environment also has an important role in determining employee performance. It includes material and psychological conditions existing within the organization. A comfortable work environment that complies a decent standard will contribute to employees comfort in performing their duties. At X hospital, there were 108 employee 
complaints (2013) and 296 service complaints (2013) related facilities and infrastructure. In addition to, the restricted parking space definitely became an obstacle for employees, patients and visitors. Patients' service complaints included unavailable tertiary Cardiovascular Installation Care Unit such as cardiovascular ambulance equipped by monitor, defibrillator with external pacing and intra-aortic balloon ventilator pump. If these facilities are optimized properly, it will help reducing patients' mortality particularly patients with coronary heart attack during they referred to $\mathrm{X}$ hospital. Another service facilitysuch as Computed Tomography Scanner is also unavailable whereas as the "Health Center of Excellence" $X$ hospital should be able to create higher efficiency, quality and excellent service most importantly onthe advanced medical equipment in order to reach a world class hospital.

\subsection{Identification of Study}

The prominent issues related to physicians" performance at X hospital are identified as follows:

a. Physicians' skills and knowledge at $X$ hospital needs to be improved through training.

b. Physicians at $X$ hospital have low learning opportunities.

c. Work environment at $X$ hospital concerning medical services is considered not optimal.

d. Physicians' achievement at $X$ hospital is relatively low.

\subsection{Formulation of Study}

The research problems can be formulated as follows:

a. Does training have a significant effect on the physicians' performance at $X$ hospital?

b. Does motivation have a significant effect on the physicians' performance at $X$ hospital?

c. Does work environment have a significant effect on the physicians' performance at $X$ hospital?

d. Do training, motivation and work environment have a significant effect simultaneously on the physicians' performance at $\mathrm{X}$ hospital?

\subsection{Objective of Study}

Objectives of this study as follows:

a. To know and to analyze the effect of training on the physicians' performance at $X$ hospital.

b. To know and to analyze the effect of motivation on the physicians' performance at $X$ hospital.

c. To know and to analyze the effect of work environment on the physicians' performance at $\mathrm{X}$ hospital.

d. To know and to analyze the effect of training, motivation and work environment simultaneously on the physicians' performance at $\mathrm{X}$ hospital.

\subsection{Benefits of Study}

Benefits of this study as follows:

a. In practically; it is expected to provide suggestion for physicians at $\mathrm{X}$ hospital particularly in giving medical services for patients

b. In technically; it is intended to examine the truth and relevance of the theories related performance evaluation. Furthermore, it is expected to provide information and an overview for enhanced by subsequent researchers.

c. In theoretically; it is expected to increase knowledge especially on models of training, motivation, work environment and physicians' performance at X hospital.

\section{Literature Review, Theoretical Framework and Hypothesis}

\subsection{Literature Review}

\subsubsection{Training}

Training is a type of learning to acquire and improve skills beyond human resource development system that is applicable in a relative short-term period[Sastradipoera, $\mathrm{K}, 2006]$ It includes overall activities in order to acquire, improve, and 
develop job competence, productivity, discipline, attitude and work ethic at certain level of skills and expertise in accordance with the level and qualification of employment. Thus, training is a kind of learning associated with efforts to change human resources behavior in order to achieve specific objectives and targets. Training program leads to increase the individual performance in their current job-oriented.

Transfer of training is emerged some circumstances such as trainees effectively and continuously applying what employees have learned at their workplace which includes knowledge, skills, behavior and cognitive strategies[Noe, R.A,2012] The process of 'transfer of training' is influenced by three factors: the character of trainees, training design and work environment that supports the training situation. Meanwhile, to ensure training runs effectively, it should be considered of four stages, namely identifying training needs, plan training programs (technical training, facilities, location and experienced trainers), training implementation and evaluation of training.[Armstrong, M.,2009] The purpose of training is to increase the knowledge and skills even to change attitudes in which it is considered as one of the most important potential motivators.[Mullins, J.L.,2005] This can lead many benefits for individuals and organizations such as increasing self-confidence, employees' commitment, recognition, responsibility and possibility of an increase salary and promotion, personal satisfaction and achievement then to expand opportunities for employee career advancement.

Training needs can be determined if there is a discrepancy among the real condition (knowledge, skills and behaviors) with the expected goals of an organization. Educational or training needs are a measurable gap between current results and expected results. Hence, Needs Assessment is very important to distinguish whether or not the deficiency can be eliminated with training performance.[Pynes, E.,2009]Through needs assessment, it should be designed and implemented training programs as a solution to identify and obtain the company goals.

Training Needs Analysis (TNA) consists of job analysis, tasks analysis and skills analysis.[Rae, L.,2005] Those are a process used to determine and to describe job responsibilities and procedures as well to get a clear understanding about each job, then it will be benefit for management to decide training needs because without this information, it will be difficult to determine the outcome, labor standards and the skills required. TNA is an initial phase before undergoing the training; it is an integral part in designing the training to obtain a comprehensive overview of its material, time allocation for each material and learning strategies applied in the training implementation in order to be useful for training participants[Mello, A.J,2011]lt should be considered of the training design due to its success depends on intensive collaborative partnerships among the main stakeholders' interests. Important activities undertaken during the requirements analysis phase include: (a) conducts due diligence training, (b) defines the function and performance process, (c) defines the affective and cognitive, (d) defines the attributes of the model, and (e) determines the learning objectives. When all phases are executed correctly, this activity then enables to generate a meaningful learning solution[Locke, A.E.,2009]

Stages of TNA is initiated withorganizational analysis.[Noe, R.A.,2012, Armstrong, M.,2009] This analysis focuses on the organization in general including the analysis of the organization's goals, resources as well as the analysis of the external and internal organization. It aims to obtain information about an organization that is used to decide training objectives to be achieved. Second is the task analysis which has a purpose to know the task to be performed by employees, performance standards setting, knowledge determination, skills and behaviors required in a job. Third is individual analysis to identify who or which employees need to train and what needs to be given.

After accomplishing capabilities measurement, then it will obtain an overview of current employee abilities. The multiple methods of data collection can use some instruments such as surveys, observation, individual interviews, focus groups, performance appraisal, gap capabilities determination and recommendation. In previous studiesstated that training had a positive effect on employee performance[Christ, 0.,2011;Masood, A.,2013]

\subsubsection{Motivation}

The term of motivation is derived from Latin, namely movere which means moving. Motivation is giving the driving force that creates the excitement of one's work to cooperate, to work effectively and to integrate with all resources in achieving satisfaction [Hasibuan, M.,2007]. Motivation arises due to two factors: an internal factor that arises from within oneself, while external factor comes from outside[Armstrong, M.,2009]. There are two types of motivation; intrinsic motivation is derived from one self to influence people in order to behave in a certain way. This factor includes the curiosity of achievement, responsibility, autonomy (freedom to act), interesting and challenging work and opportunities for advancement. While extrinsic motivation is a kind of motivation to motivate others. It includes benefits, such as salary increases, appraisal, promotion, and punishment such as disciplinary action, pay cuts or criticism.

Another theory of Maslow's hierarchy of needs model is proposed by Abraham H. Maslow. In this theory, humans 
are motivated to behave or to perform activities because of the various necessities of life.[Daft, L.R.,2010]. First, selfactualization needs, that is the use of self-potential, growth, self-development as completing assignments that are challenging, creative work and skills development. Second, need for self-esteem namely the status or position, confidence, reputation and achievements, self-respect, appreciation such as power, ego, promotion, gifts, status, symbol, recognition, titles or awards. Third, social need is love, compassion, friendship, sense of belonging and kinship. Fourth, need for safety and security, namely the protection and stability as employee development, safe working conditions, seniority unions planning, savings, severance pay, pension, insurance and complaint handling system. Fifth, physiological needs include food, housing, sex, break, clean air to breathe, water to drink, vacation, remuneration and social security.

Another motivation theory is proposed by Clayton Alderfer. This theory is a simplification and further development of the theory of Abraham Maslow's hierarchy of needs: (1) Existancy is a requirement that would be able to live up to the lower level which include physiological and security needs. (2) Relatedness or relationships is the need to interact with others such as need for affiliation. (3) Growth is a necessity that drives a person to have a creative and productive influence toward oneself or environment. It includes the need for respect and self-realization[Pynes, E.,2009]

Meanwhile, Frederick Herzberg in his theory is classified into two factors: (1) Factors that cause dissatisfaction (hygiene/Maintenance). Hygiene factors motivate a person to release from dissatisfaction including human relations, benefits, environmental conditions, and so forth (extrinsic factors). The hygiene factors involve salaries, wages, company policy, interpersonal relationships, quality control, job security, working conditions and the balance of work and life. (2) Factors causing job satisfaction (motivators) which directly related to job content or intrinsic factors. It motivates oneself to get satisfaction such as achievement, recognition, advancement level of life, etc. [Mullins, J.L.,2005]

Furthermore, Motivation consists of need for achievement, need for power and need for affiliation[lvanko, S., 2012.] In previous studiesstated that motivation had positive effect on employee performance[Kiruja, 2013; Awosusi,2011]

\subsubsection{Work Environment}

Towers Perin argues that work environment is able to create motivation and reward if it is supported by nine factors: core values of the organization, leadership, employee aspirations, achievement, recognition, development and role of work design, quality of work life, balance at the work and talent management.[Armstrong, M.,2009]

Physical work environment is a whole or any aspect of the physical symptoms and socio-cultural that surrounds or influences individual.[Komarudin,2002] Service employees who are not placed properly will result in a wide variety of losses of the company concerned. While working condition is a condition that is prepared by the management company in caring employees appropriately. Physical work environment can be improved through creating companies layout such as coloring, lighting, air, space, security and cleanliness.

Meanwhile, non-physical work environment can only be felt but not seen, heard or touched by human senses. It can be developed through creating human relations as well as possible between leaders and employees or among coworkers.[Ivanko, S.,2012] Therefore, to create a pleasant non-physical work environment, it can be realized through creating good human relations. In addition, leaders can also provide services to employees so that they feel safe and comfortable at the workplace due to their psychological needs already completed.

In sum up, physical and non-physical work environment should always be taken by the organization. Both cannot be separated but it would be better if they are implemented optimally. Therefore, the role of a leader should be able to create a good working environment then it is automatically able to improve the employees' performance. In previous study, stated that work environment had a positive effect on employees' performance[Naharuddin,2013]

\subsubsection{Physicians' Performance}

Armstrong argues that the performance is a combination of behavior and output of the employees in completing the outcome[Armstrong, M.,2009]Furthermore, human resource performance is a term derived from job performance or actual performance to attain employee achievement.[Mangkunegara,2007] In previous studies, training, motivation and work environment had positive effect on employees' performance.[ Parlinda, V.,2013; Munparidi,2012]Performance excellence is one of the major factors that must be pursued by each organization to win the global competition, as well as by health care service providers. To improve the performance of hospitals, physicians are required to fulfill the basic tasks in the diagnosis, medical treatment, disease prevention, clinical improvement and restoration, education, training and research development of medical services. 
The Indonesian government has made several regulations on increased performance and competency standards of Indonesian physicians, standards of hospital education and other medical facilities. Indonesian Medical Council as a regulator of the medical profession as mandated on the medical practice has duties and authorities to lead physicians to fulfill their performance and achievement in accordance with the progress of science and medical technology as an effort to address the needs of quality assurance for patients' safety in the organization of the practice medicine. It is further organized in the Indonesian Medical Council on the legalization competency and performance standards that physicians should be adjusted with the development of science and medical technology. Physicians' Performance is categorized into seven pillars:[KKI,2012]

1) Sublime professionalism; devoting Almighty, moral, ethics and professional behavior.

2) Self-awareness and personal development; self-introspection, lifelong learning and developing knowledge.

3) Effective communication; communicate with patients and their family, partners and public.

4) Information management; accessing and assessing information and knowledge as well as the information and knowledge dissemination effectively of medical professionals, patients, public and stakeholders to improve the quality of medical services.

5) Scientific medical sciences; applying biomedical sciences, humanities sciences, clinical sciences and medical prevention/medical community to manage health problems holistically and comprehensively.

6) Clinical skills; performing diagnostic procedures holistically.

7) Management of health problems; implementing medical prevention, early detection and management of health problems on individuals, families and collaborating with the community as an effort to improve the health to manage resources effectively, efficiently and sustainable in solving health problems in Indonesia respectively.

\section{Theoretical Framework}

Hospital is the most important part of a health system due to it provides complex curative services, emergency services as a referral center and a center for transfer of knowledge and technological in medical practices. One of prominent investments made by the hospital is human investment with funds allowance and provision for the benefit of physicians' training. Training is a force that is expected to accelerate the development of human resources with competence, ability and professionalism in accordance with the demands of current job.

Another continuous effort which is developed by management in improving the employees' performance is motivation. However at $X$ hospital, the spirit of self-actualization and self-achievement owned by physicians still need to be improved in order to achieve international standard hospitals $\mathrm{JCl}$ (Joint Commission International). The spirit that must be developed such as motivation to creativity, creating the ideas / notion, continuing to pursue higher education (magister/specialist/doctorate program/consultant) and conducting research related to current disease and treatment.

Physicians' performance is also influenced by work environment. Work environment is divided into material and psychological conditions exist in the workplace. In order to the physicians are able to work optimally, it is necessary to create a safety, comfort and fresh work environment, it is also completed with well-equipped facilities and infrastructure so that working efficiency can be achieved. Besides, human relations among physicians, between nurses and physicians, between administration staffs with physicians, support from the leader must be nurtured properly, thus physicians continually provide their best service and improve hospital performance. To know the effect of training, motivation and work environment on the physicians' performance, it is then created a theoretical framework. Training, motivation and work environment is indicated as independent variables, while physicians' performance is indicated as a dependent variable. The relationship between independent and dependent variables in this study is described in the following framework:

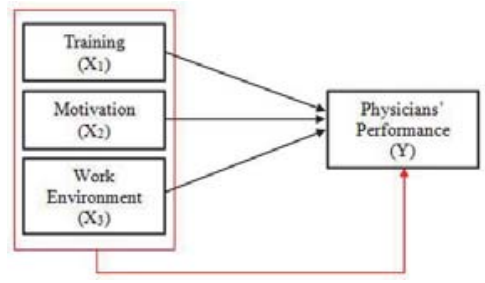

Figure 1. Theoretical Framework 


\section{Research Hypothesis}

The research hypotheses are formulated as follows:

$\mathrm{H1}$ : Training has a significant effect on physicians' performance at $\mathrm{X}$ hospital.

$H 2$ : Motivation has a significant effect on physicians' performance at $X$ hospital.

H3: Work environment has a significant effect on physicians' performance at $X$ hospital.

H4: Training, motivation and work environment has a significant effect simultaneously on physicians' performance at $\mathrm{X}$ hospital.

\section{Method of Research}

This research was conducted through a quantitative method; a method of research that aims to test the hypothesis. This explanatory descriptive research is based on observations toward consequences occurrence (physicians' performance) and determine the factors that may be its causes (training, motivation and work environment) through collecting data and information taken from 84 samples of existing population at $X$ hospital by using questionnaires 1-5 Likert scale, then analyzed to obtain accurate data related to the facts and relationship among variables. The formulated hypothesis was taken then tested using Pearson Correlation generated by SPSS 21 program. The method of data analysis consists of validity and reliability instrument test, normality test, multicollinieary test, heteroscedasticity test, $\mathrm{F}$ and $\mathrm{t}$ hypothesis test.

Table 3. Operational Variables

\begin{tabular}{|c|c|c|c|}
\hline Variables & Theory & Dimensions & Indicators \\
\hline$\overline{\text { Training }\left(\mathrm{X}_{1}\right)}$ & $\begin{array}{l}\text { Training is a short-term educational } \\
\text { process that uses a sistematic and } \\
\text { organized procedure in which employees } \\
\text { learn technical knowledge in a limited } \\
\text { purpose.[21] }\end{array}$ & $\begin{array}{l}\text { Instructor }\left(X_{1.1}\right) \\
\text { Participant }\left(X_{1.2}\right) \\
\text { Material }\left(X_{1.3}\right) \\
\text { Method }\left(X_{1.4}\right)\end{array}$ & $\begin{array}{l}\text { Skills owned by trainers } \\
\text { Creativity of trainers } \\
\text { Motivation owned by trainees } \\
\text { Discipline \& spirit of trainees } \\
\text { Training material provided } \\
\text { Application of the theory } \\
\text { Timing of the training } \\
\text { Strategic management training } \\
\text { strategy } \\
\text { Creation of learning environment } \\
\text { Conducive relationship and } \\
\text { atmosphere } \\
\text { Supporting technology } \\
\text { Convenience training } \\
\text { Benefits of training } \\
\text { Support from management and } \\
\text { co-workers } \\
\text { Opportunity to develop }\end{array}$ \\
\hline Motivation $\left(\mathrm{X}_{2}\right)$ & $\begin{array}{l}\text { Motivation is oneself desire that causes the } \\
\text { person to behave in a certain way for a } \\
\text { reason to achieve the goal. [5] }\end{array}$ & $\begin{array}{l}\text { Intrinsic } \\
\text { Motivation }\left(X_{2.1}\right) \\
\text { Extrinsic motivation } \\
\left(X_{2.2}\right)\end{array}$ & $\begin{array}{l}\text { The desire for achievement } \\
\text { The desire to advance in career } \\
\text { The desire for responsible } \\
\text { The desire to realize ideas } \\
\text { The desire to be professional } \\
\text { The desire to share knowledge } \\
\text { The desire to learn } \\
\text { Type of work } \\
\text { Work status } \\
\text { Eligible income } \\
\text { Protection / medical insurance } \\
\text { Recognition } \\
\text { Good leadership } \\
\text { Wisdom administration } \\
\text { Good management policy }\end{array}$ \\
\hline $\begin{array}{l}\text { Work } \\
\text { Environment }\left(\mathrm{X}_{3}\right)\end{array}$ & $\begin{array}{l}\text { Work environment is a set of terms of the } \\
\text { environment perceived by people who } \\
\text { work within the organization and has a } \\
\text { large role in influencing employee }\end{array}$ & $\begin{array}{l}\text { Physical } \\
\text { Environment }\left(X_{3.1}\right)\end{array}$ & $\begin{array}{l}\text { Fulfillment of work equipment } \\
\text { Cleanliness condition } \\
\text { Lighting condition } \\
\text { Temperature condition }\end{array}$ \\
\hline
\end{tabular}




\begin{tabular}{|c|c|c|c|}
\hline & behavior.[3] & $\begin{array}{l}\text { Non-physical } \\
\text { environment }\left(X_{3.2}\right)\end{array}$ & $\begin{array}{l}\text { Air circulation condition } \\
\text { Noise conditions } \\
\text { Smelling condition } \\
\text { Arrangement of colors and } \\
\text { decorations } \\
\text { Safety at workplace } \\
\text { Relationship between superiors } \\
\text { and subordinates } \\
\text { Relationship among co-workers } \\
\text { Relationship between } \\
\text { management \& employees } \\
\text { Management Policy } \\
\text { Convenience interact with co- } \\
\text { workers } \\
\text { Relationship among management } \\
\text { co-workers }\end{array}$ \\
\hline $\begin{array}{l}\text { Physician } \\
\text { Performance(Y) }\end{array}$ & $\begin{array}{l}\text { Physicians' performance are constructed } \\
\text { by competencies consisting of } \\
\text { professionalism, self-introspection and } \\
\text { personal development, effective } \\
\text { communication; supported by some pillars } \\
\text { such as information management, } \\
\text { scientific medical sciences, clinical skills } \\
\text { and management of health problems.[24] }\end{array}$ & $\begin{array}{l}\text { Professionalism }\left(\mathrm{Y}_{1.1}\right) \\
\text { Self-introspection and } \\
\text { personal development } \\
\left(\mathrm{Y}_{1.2}\right) \\
\text { Effective communication } \\
\left(\mathrm{Y}_{1.3}\right) \\
\text { Information } \\
\text { management }\left(\mathrm{Y}_{1.4}\right) \\
\text { Scientific medical } \\
\left.\text { sciences ( } \mathrm{Y}_{1.5}\right) \\
\text { Clincial skills }\left(\mathrm{Y}_{1.6}\right) \\
\text { Management of medical } \\
\text { problems }\left(\mathrm{Y}_{1.7}\right)\end{array}$ & $\begin{array}{l}\text { Devout Almighty } \\
\text { Moral and ethics } \\
\text { Behave professionally } \\
\text { Self-introspection } \\
\text { Lifelong learning } \\
\text { Develop new knowledge } \\
\text { Communication with patients and } \\
\text { their families } \\
\text { Communication with co-workers } \\
\text { Medical information technology } \\
\text { Applied biomedical sciences and } \\
\text { medical public } \\
\text { Effectiveness and efficiency of } \\
\text { the treatment } \\
\text { Performing diagnostic procedures } \\
\text { Performing clinical and laboratory } \\
\text { procedures. } \\
\text { Performing clinical emergency } \\
\text { procedures } \\
\text { Reporing patients' medical } \\
\text { treatment result } \\
\text { Improving clinical status }\end{array}$ \\
\hline
\end{tabular}

\section{Finding and Discussion}

\subsection{Respondent Profile}

Table 4 stated $X$ hospital did not employ physicians based on sex, but it was seen from the profession conformity. The productive physicians should be more skilled though most of them are already qualified as cardiologists. Thus, $\mathrm{X}$ hospital already qualified as type-A hospital in treating patients with cardiovascular diseases.

Table 4. Respondent Characteristics

\begin{tabular}{|c|c|c|c|}
\hline No & Respondent Characteristic & Frequency & Percentage \\
\hline \multirow[t]{3}{*}{1} & Sex & & \\
\hline & Male & 58 & 69,05 \\
\hline & Female & 26 & 30.95 \\
\hline \multirow[t]{5}{*}{2} & Age & & \\
\hline & $<40$ & 10 & 11.9 \\
\hline & $41-50$ & 24 & 28.57 \\
\hline & $51-60$ & 21 & 25 \\
\hline & $>60$ & 29 & 34.52 \\
\hline \multirow[t]{3}{*}{3} & Academic & & \\
\hline & Bachelor degree & 7 & 8.33 \\
\hline & Magister degree / Specialist & 64 & 76.19 \\
\hline
\end{tabular}




\begin{tabular}{|c|c|c|c|}
\hline & Doctoral degree / Consultant & 13 & 15.47 \\
\hline \multirow[t]{4}{*}{4} & Period of Work & & \\
\hline & $1-10$ years & 32 & 38,1 \\
\hline & $10-20$ years & 20 & 23.81 \\
\hline & $>20$ years & 32 & 38.1 \\
\hline \multirow[t]{12}{*}{5} & Functional Medical Staff Unit & & \\
\hline & Cardiologist & 10 & 11.9 \\
\hline & Pediatrician & 43 & 51.19 \\
\hline & Radiologist & 3 & 3.57 \\
\hline & Neurologist & 3 & 3.57 \\
\hline & Clinical Nutrition Specialist & 1 & 1.19 \\
\hline & Pulmonologist & 1 & 1.19 \\
\hline & Pathologist & 1 & 1.19 \\
\hline & Anesthesiologist & 2 & 2.38 \\
\hline & Dentist & 12 & 14.29 \\
\hline & General Practitioner & 3 & 3.57 \\
\hline & Cardiologist & 5 & 5.95 \\
\hline
\end{tabular}

Source: Data processed by the author (2014)

\subsection{Descriptive Statistic of Research Variables}

Table 5 stated that variables of motivation, work environment and physicians' performance had minimum value was 1 and maximum value 5 . Thus, all variables could be still improved.

Table 5. Descriptive Statistic of Research Variables

\begin{tabular}{llccc}
\hline Variables & Dimensions & Min. & Max. & Mean \\
\hline Training & Instructor & 2 & 5 & 3.61 \\
& Participant & 2 & 5 & 3.57 \\
& Material & 2 & 5 & 3.65 \\
& Method & 2 & 5 & 3.68 \\
& Objective & 1 & 5 & 3.39 \\
& Target & 2 & 5 & 3.56 \\
\hline Motivation & Intrinsic & 2 & 5 & 3.53 \\
& Extrinsic & 2 & 5 & 3.53 \\
\hline Work & Physical & 2 & 5 & 3.61 \\
Environment & Non-physical & 2 & 5 & 3.56 \\
\hline \multirow{5}{*}{ Physicians' } & Professionalism & 2 & 5 & 3.77 \\
Performance & Self-introspection & 2 & 5 & 3.49 \\
& E personal development & 1 & 5 & 3.68 \\
& Information management & 1 & 5 & 3.79 \\
& Scientific medical sciences & 1 & 5 & 3.57 \\
& Clinical skills & 2 & 5 & 3.49 \\
& Management of health problems & 3 & 5 & 3.76 \\
\hline
\end{tabular}

Source: SPSS 21 output (2014)

\subsection{Validity and Reliability Instrument Test}

Table 6 stated that the questionnaire is declared valid andreliable. 
Table 6. Validity and Reliability Test Result

\begin{tabular}{|c|c|c|c|}
\hline Variables & Dimensions & Pearson Correlation & nbach Alpha \\
\hline \multirow[t]{6}{*}{ Training } & Instructor & $0.395^{\text {t* }}$ & \multirow{6}{*}{0.892} \\
\hline & Participant & $0.452^{2 *}$ & \\
\hline & Material & $0.527^{\text {t* }}$ & \\
\hline & Method & $0.472^{* *}$ & \\
\hline & Objective & $0.524^{* *}$ & \\
\hline & Target & $0.391^{* *}$ & \\
\hline \multirow[t]{2}{*}{ Motivation } & Intrinsic & $0.393^{\text {t* }}$ & \multirow{2}{*}{0.856} \\
\hline & Extrinsic & $0.434^{* *}$ & \\
\hline \multirow[t]{2}{*}{ Work Environment } & Physical & $0.443^{\text {t* }}$ & \multirow{2}{*}{0.838} \\
\hline & Non-physical & $0.525^{\text {t* }}$ & \\
\hline \multirow{7}{*}{ Physicians' Performance } & Professionalism & $0.436^{* *}$ & \multirow{7}{*}{0.789} \\
\hline & $\begin{array}{l}\text { Self-introspection } \\
\text { \& personal development }\end{array}$ & $0.471^{*+*}$ & \\
\hline & Effective communication & $0.484^{* *}$ & \\
\hline & Information management & $0.455^{*+}$ & \\
\hline & Scientific medical sciences & $0.379^{* *}$ & \\
\hline & Clinical skills & $0.375^{* *}$ & \\
\hline & Management of health problems & $0.415^{* *}$ & \\
\hline
\end{tabular}

Source: SPSS 21 output (2014)

\subsection{Normality Test}

Table 7 showed the residual significance on variables of training, motivation, work environment and physicians' performance were higher than $p$-value 0.05 . Thus, it could be indicated that variable residuals are distributed normally.

Table 7. One-Sample Kolmogorov-Smirnov Test

\begin{tabular}{lc}
\hline Variables & Asymp. Sig (2-tailed) \\
\hline Training & 0.268 \\
Motivation & 0.454 \\
Work Environment & 0.531 \\
Physicians' Performance & 0.773 \\
\hline
\end{tabular}

Source: SPSS 21 output (2014)

\subsection{Multicollinearity Test}

Table 8 was obtained tolerance value on variables of training, motivation and work environment was greater than 0.10 and less than 10.00 variance inflation factors. Thus, the data was not occur multicollinearity problem, meaning that there was no independent variable that must be eliminated in the proposed model.

Table 8. Multicolliniearity Test Result

\begin{tabular}{lccc}
\cline { 2 - 3 } \multicolumn{2}{c}{ Model } & \multicolumn{2}{c}{ Collinearity Statistics } \\
\cline { 2 - 4 } & Training & 0.610 & VIF \\
Motivation & 0.814 & 1.638 \\
Work Environment & 0.527 & 1.228 \\
\cline { 2 - 3 } & & & 1.899 \\
\hline
\end{tabular}

Dependent Variable: Physicians' Performance

Source: SPSS 21 output (2014) 


\subsection{Heteroscedasticity Test}

Figure 2 showed there was not found particular pattern (above and below the number 0 on the $Y$ axis). Thus, regression had no occur heteroscedasticity and the regression model was able to be used to predict physicians' performance based on the variables input of training, motivation and work environment.

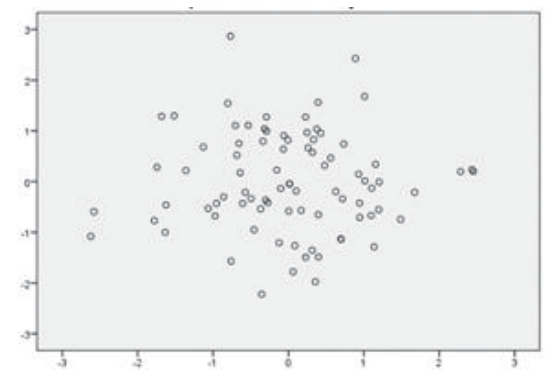

Figure 2. Scatter Plot of Heteroscedasticity Test

Source: SPSS 21 output (2014)

\subsection{Analysis of Multiple Linier Regressions}

Table 9. Variable Regression of Training, Motivation and Work Environment on Physicians' Performance

\begin{tabular}{lcc}
\hline Model & Coefficients & Sig. \\
\hline (Constant) & 2.527 & 0.004 \\
Training & 0.011 & 0.854 \\
Motivation & 0.432 & 0.000 \\
Work Environment & 0.455 & 0.000 \\
\hline R Square & $71.6 \%$ & \\
\hline F & & 0.000 \\
\hline
\end{tabular}

Source: SPSS 21 output (2014)

Based on Table 9, constants ( $\beta 0) 2.527$ meant significant if there was no effect on the three independent variables (training, motivation and work environment) then the value of physician performance is 2.527 . In this case, the physicians' performance was bad. Meanwhile motivation variable contributed significant effect ( $\beta 2$ ) 0.432 on physicians' performance. Then, work environment variable contributed significant effect ( $\beta 3) 0.455$ on physicians' performance. This regression was formulated as following:

$$
Y=2.527+0.011 X_{1}+0.432 X_{2}+0.455 X_{3}
$$

\subsection{Coefficient of Determination}

The coefficient of determination $\left(\mathrm{R}^{2}\right)$ based on Table 9 was known 0.716 . That is, training, motivation and work environment explained $71.6 \%$ variances on physicians' performance. Meanwhile $28.4 \%$ was explained by other unexamined variables.

\subsubsection{F Hypothesis Test}

$F$ hypothesis test will be significant if $p$-value is greater than 0.05 , then $\mathrm{Ho}$ is accepted. If $p$-value is less than 0.05 , then $\mathrm{Ho}$ is rejected. Based on Table 9, it was obtained $p=0.000<0.05$, then Ho was rejected. Thus, variables of training, motivation and work environment had simultaneously significant effect on physicians' performance. 


\subsection{2 t Hypothesis Test}

t hypothesis test will be significant if $p$-value is greater than 0.05 , then $\mathrm{Ho}$ is accepted. If $p$-value is less than, then $\mathrm{Ho}$ is rejected. Based on Table 6, it was known training variable $p=0.854>0.05$ in which $\mathrm{Ha}$ is rejected and $\mathrm{Ho}$ accepted. Thus, training in partially had no significant effect on physicians' performance. Furthermore, motivation variable $\mathrm{p}=0.000$ $<0.05$ in which $\mathrm{Ho}$ is rejected and Ha accepted. Thus, motivation in partially had significant effect on physicians' performance. Last, work environment variable $p=0.000<0.05$ in which Ho is rejected and Ha accepted. Thus, work environment in partially had significant effect on physicians' performance.

\section{Dimensional Correlation Matrixamong Dimensions}

The correlation coefficient $(r)$ aims to determine the most dominant effect of independent variables dimensions on the dependent variable dimensions.

Table 10. Dimensional Correlation Matrix

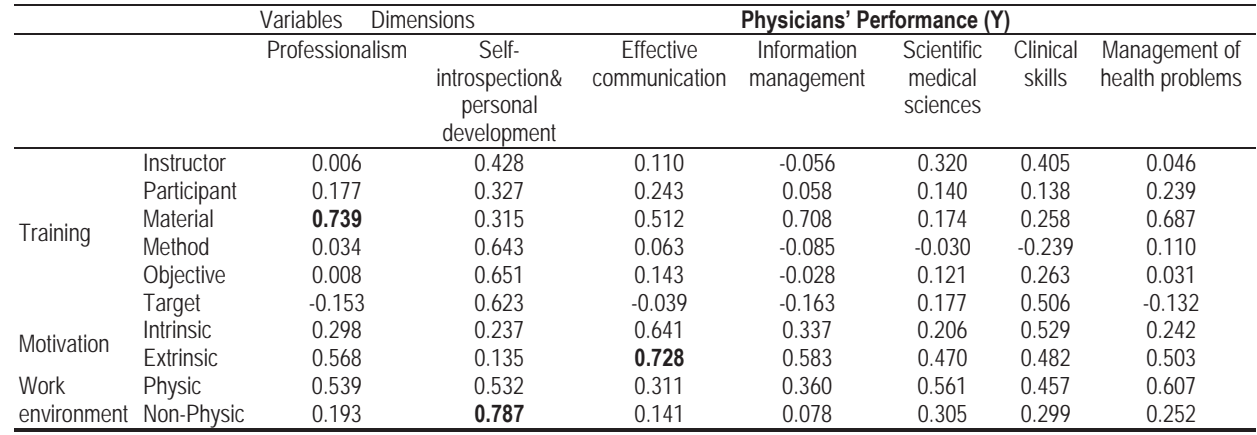

Sources: SPSS 21 output summarized by the author (2014)

Table 10 concluded that the dominant dimension on motivation variable was the dimension of extrinsic motivation toward effective communication. Besides, the dominant dimension on work environment variable was the dimension of nonphysical work environment toward self-introspection and personal development.

\section{Discussion and Research Finding}

First, the research found that training variable had no significant effect on physicians' performance. Its finding in the previous study that some of the reasons why training had no effect; it is caused by the benefits of training are not clear for top management, top management does not give awards to the instructors to implement effective training, top management does not pay attention systematically plan and budget for training. In addition to during training evaluations, the instructors just provide limited counseling services. Meanwhile, according to Armstrong, training is a skill improvement process that is carried out in a short period of time which should be designed in a systematic and specific way.[Armstrong, M.,2009] Hence, it enables to know how to train properly and the impact of training should be evaluated carefully. Related with period of training at $X$ hospital especially on echo-cardiographic techniques training is implemented in two stages so it spent quite a long time and lots of budget. In the first phase, the training was supervised for at least 6 months or until the number of cases required by the participants as a graduation requirement. Meanwhile in the second stage, it is an independent program for 6 months performed in the institution of the participants concerned. This stage is to practice the skills they have learned, completing academic tasks such as conducting research and scientific publications for general practitioners and specialists. Then, regarding the evaluation of training, management of $X$ hospital underwent an evaluation parameter assessed based on daily activities observation, pre-test and post-test, logbook, academic activities such as scientific papers, special reports and research. However, feedbacks from the 
evaluation results had not been obtained by the trainees. This implied that Training and Education division at X hospital should develop medical skill of cardiovascular disease modules and drafting applicable training. Therefore, the management of $X$ hospital should be able to give feedback in motivating and supporting physicians both financial and non-financial.

Second, the study showed that motivation had significant effect in partially on physicians' performance. Thus, the level of performance is automatically influenced by the level of motivation itself. Its finding was in line with several previous study, motivation had significant effect on employee performance.[Kiruja,2013]In addition to, motivation is a psychological process that reflects the interaction among attitudes, needs, perceptions and decisions that occur in a person.[Armstrong, M.,2009]Motivation is defined as the whole process of giving encouragement or stimulant to the employees so that they are willing to cooperate without force. This implies that management of $X$ hospital should increase physicians' motivation so that they are eager to accomplish their work dedicatedly. It includes an increasing salary based on the role and loyalty, permanent employee status, compensation, protection / health insurance, awards, promotions, disciplinary actions, etc. If those are repaired and improved, it will improve physicians' performance at $X$ hospital. Then, the dominant dimension of motivation variable is extrinsic motivation toward effective communication. This means that if the management at $X$ hospital is able to increase the physicians' extrinsic motivation, then the effective communication among physicians will automatically increase. It can be enforced by adding incentives and rewards for them who are willing to continue pursuing a doctoral academic program so that Cardiology Division in $\mathrm{X}$ institution is able to fulfill the qualification demands of lecturers in educating specialists.

Third, the result showed that work environment had significant effect in partially on physicians' performance. This finding was in line with previous studies,that is, the better the work environment is created, the better the performance will get or vice versa.[Kahya, E.,2007; Ollukkaran, B.A.,2012] Work environment is the leader's responsibility to create human relations as well as possible between the leadership and employees or among co-workers.[Ivanko, S.,2012] Implications for $\mathrm{X}$ hospital, the management must create an effective communication in the workplace between superiors and subordinates, peers among physicians, management with physicians, physicians with nurses and administration staff at $X$ hospital. Furthermore, the dominant dimension of work environment variable is the dimension of non-physical work environment toward self- introspection and personal development. This means that if the management of $X$ hospital is able to increase non-physical work environment favorably, then physicians' self-introspection and self-improvement will automatically increase. It can be applied by the Management of $X$ hospital to create a team work and gathering not only for physicians but also for all medical stakeholders such as nurses and administration staff in order to establish harmonious atmosphere to interact with co-workers. Thus, it would be benefit to provide the best medical service for patients.

Fourth, the result showed motivation and work environment had significantly effect simultaneously on physicians' performance. This finding was in line and supported with previous studies.[Munparidi,2012;, Azar, M.2013]Indonesian Medical Council related with the term of medical practices has the authority to trigger the physicians to meet their performance and achievements in accordance with the progress of medical science and technology as well as the efforts to achieve patient safety in implementing medical practices.[KKI,2012] Thus, the variables of motivation and work environment significantly affect on increasing or decreasing physicians' performance at X hospital. X hospital management should have to provide high motivation to create many achievements for the physicians and to create a safety and comfort work environment.

\section{Conclusion and Suggestion}

\subsection{Conclusion}

The conclusion of this research as follows:

1) Training has no significant effect on physicians' performance at $X$ hospital.

2) Motivation has significant effect on physicians' performance at $X$ hospital.

3) Work environment has significant effect on physicians' performance at $X$ hospital.

4) Motivation and work environment has significant effect simultaneously on physicians' performance at $X$ hospital. 


\subsection{Suggestion}

In this section, the author would like to provide some intakes that can be used as consideration for the management at $X$ hospital in determining future policy. First, the implications for the management of $X$ hospital, they should create a communicative and interactive atmosphere and harmonious human relations between superiors and subordinates, peers among physicians, the management with physicians, physicians with nurses and administration staff involved. To create a conducive relationship among physician colleagues particularly on patients' referral, the leader of $X$ hospital should create the team work completed with its standard operating procedures referring to the regulation of Indonesian Medical Council with emphasis on patients' safety. This team work is continuously monitored and evaluated appropriately within medical records, then among physicians no need to hesitate to undergo patients' referral to another physician colleagues who more qualified and relevant in their competency. Likewise, the relationship between physicians with nurses and administration staff will be integrated in serving the patients well. Then, to create a harmonious working atmosphere among physicians, nurses and other staffs, the management of $X$ hospital should create gathering/outbound for all medical stakeholders in order to establish create a comfort interaction with all colleagues and also to minimize the pressure and gaps in the work environment.

Second, the implications for the management of $X$ hospital should have to fulfill what the physicians' expectations such as fair compensation based on performance results, medical insurance, simply and straightforward policy administration services. In addition, management of X hospital should accommodate physicians' psychological needs including appreciation and fair incentives based on their academic level. This is implemented in order to motivate them to continue their studies to pursue a doctoral program so Cardiology Division at $\mathrm{X}$ institution is able to meet the qualification criteria for a specialist lecturer.

\section{References}

Afshan, E., The Effect of Training on Employee Performance. European Journal of Business and Management, 2012. 5(4): p. $137-147$. Armstrong, M., Human Resource Management. 2009, London: Kogan Page Limited.

Azar, M. and A.A. S., The Effect of Work Motivation on Employees' Job Performance (Case Study: Employees of Isfahan Islamic Revolution Housing Foundation). International Journal of Academic Research in Business and Social Sciences, 2013. 3(9): p. 432-445.

Awosusi, Motivation and Job Performances among Nurses in the Ekiti State of Nigeria. International Journal of Pharma and Bio Science, 2011. 2(2): p. 583-595.

Christ, O., Employee Training and Development in Nigerian Organisations. Australian Journal of Business and Management Research, 2011. 1(9): p. 82-91.

Daft, L.R., Understanding the Theory and Design of Organizations. 10th ed. 2010, South-Western: Nelson Education Ltd.

Hasibuan, M., Human Resource Management, 2007, Jakarta: Bumi Aksara.

Ivanko, S., Organizational Behavior. 2012, Ljubljana: University of Ljubljana.

Kahya, E., The Effects of Job Characteristics and Working Conditions on Job Performance. International Journal of Industrial Ergonomics, 2007: p. 515-523.

Kiruja, Effect of Motivation on Employee Performance in Public Middle Level Technical Training Institutions in Kenya. International Journal of Advances in Management and Economics, 2013. 2(4): p. 73-84.

KKI, The Law of The Republic Indonesia No. 29, 2004 About Practice of Medicine. 2012, KKI: Jakarta.

Komarudin, Encyclopedia of Management. 2002, Jakarta: Bumi Aksara.

Locke, A.E., Principles of Organizational Behavior. London. 2009, Wiley.

Mangkunegara, Human Resource Management 2007, Bandung: PT. Rosdaremajakarya.

Masood, A., Impact of Motivation on Employee Performance with Effect of Training: Specific to Education Sector of Pakistan. International Journal of Scientific and Research Publication, 2013. 3(9): p. 1-9.

Mello, A.J., Strategic Management of Human Resources. 3rd ed. 2011, South-Western: Engage Learnin

Mullins, J.L., Management and Organizational Behavior. 2005, London: Prentice Hall.

Munparidi, Effect of Leadership, Training, Motivation and Work Environment On Employee Performance At PDAM Tirta Musi. Journal of Business VII, 2012: p. 47-54.

Naharuddin, Factors of Workplace Environment that Affect Employees Performance: A Case Study of Miyazu Malaysia. International Journal of Independent Research and Studies, 2013. 2(2): p. 66-78.

Noe, R.A., HRM: Gaining a Competitive Advantage. 2012, New York: McGraw-Hill.

Nupur, C., Impact of Employee Motivation on Performance. International Journal of Business Trends and Technology, 2012. 2(4): p. 2935.

Ollukkaran, B.A., A Study on the Impact of Work Environment on Employee Performance, 2012, School of Management and Entrepreneurship Development, Bharathiar University. p. 1-16. 
Parlinda, V., Effect of Motivation, Leadership, Training and Work Environment On Employee Performance at PDAM Surakarta 2013, UMS. p. 1-16.

Pynes, E., Human Resource Management for Public and Nonprofit Organizations: A Strategic Approach. 2009, San Francisco: JosseryBass.

Rae, L., The Art of Training and Development: Effective Planning: Translated by Fiyanti Osman. 2005, Jakarta: PT Bhuana Ilmu Populer. Sastradipoera, K., Training and Development : Human Resource Management Approach. 2006. Bandung : Kappa Sigma.

Sultana, A. and K. A., Impact of Training on Employee Performance. Institute of Interdisciplinary Business Research, 2012. 4(6): p. 646661. 
